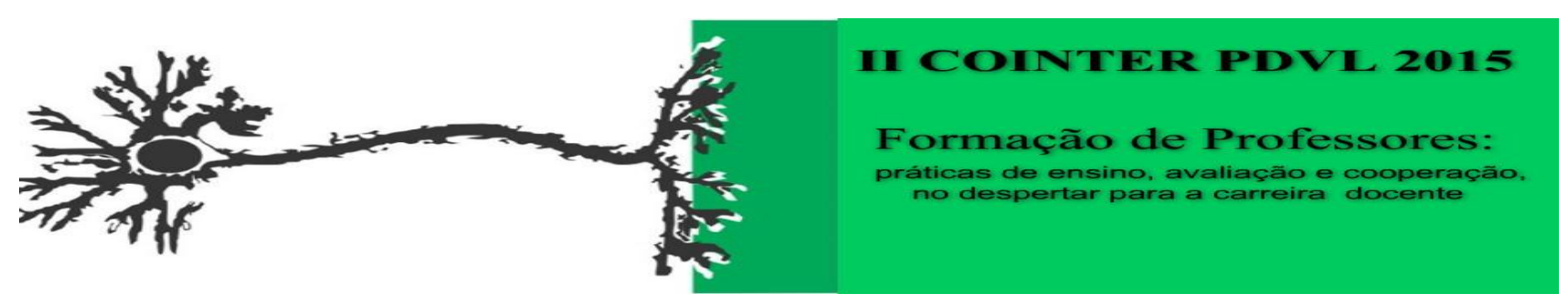

\title{
OS SABERES DA DOCÊNCIA EXPERIENCIADOS NO PIBID A PARTIR DAS CONTRIBUIÇÕES DA PSICOLOGIA DO DESENVOLVIMENTO
}

\author{
Dayane Wanessa de Souza Dias ${ }^{1}$; Mirtes Ribeiro de Lira ${ }^{2}$.
}

Apresentação: Relato de Experiência

\section{Introdução}

O presente trabalho relata a experiência vivenciada na monitoria de iniciação docência promovida pelo Programa de Fortalecimento da Universidade de Pernambuco, no curso de Licenciatura de Matemática e no $2^{\circ}$ período e no curso de Licenciatura de Letras/Espanhol, $5^{\circ}$ período, da Universidade de Pernambuco campus Mata Norte, nos quais foi vivenciada a disciplina Psicologia do Desenvolvimento. A disciplina Psicologia do Desenvolvimento é oferecida em todos os semestres como disciplinas obrigatórias nos cursos de Licenciatura da UPE/Mata Norte. A monitoria teve como objetivo maior despertar o interesse do estudante-monitor pela docência e pela pesquisa, mediante o desempenho de atividades ligadas ao ensino, possibilitando a experiência da vida acadêmica. As estratégias de acompanhamento e avaliação das atividades da monitoria foram efetivadas da seguinte forma: observação, registros de frequência, fichas de registro, diário de campo e relatório das atividades executadas pela professora.

\section{Relato de Experiência}

A monitoria foi desenvolvida em duas partes complementares: a participação nas atividades de planejamento e cumprimento das atividades correspondentes; e no engajamento no grupo de pesquisa colaborando com a produção acadêmica para futura divulgação. Durante a monitoria, em contato direto com os estudantes, pude observar as dificuldades que a maioria dos alunos, do Curso de Licenciatura em Matemática, sente em estudar e compreender disciplinas das áreas de humanas, pois ao iniciarem o curso, pensam que só irão estudar disciplinas na área de exatas, e com isso valorizam as disciplinas específicas do Curso. No decorrer do curso, quando percebem que também irão estudar disciplinas de Ciências Humanas, como, por exemplo, Psicologia do Desenvolvimento entram em conflito consigo mesmos, por acharem que não darão conta dos conteúdos, por vezes

\footnotetext{
${ }^{1}$ Graduanda curso de Pedagogia, Universidade de Pernambuco campus Mata Norte, dayane.folck@gmail.com

2 Doutora em Educação, Universidade de Pernambuco campus Mata Norte, mirtes.lira@upe.br
} 
complexos. Entretanto, no decorrer da disciplina Psicologia do desenvolvimento, percebem o quanto é importante os saberes conduzidos pela referida disciplina, para sua formação docente, pois muitas questões que encontrarão no cotidiano da sala de aula vão remeter aos conteúdos estudados na referida disciplina. Observou-se que embora, com grande dificuldade, demonstraram interesse com a disciplina e envolvimento nos exercícios realizados individuais e em grupos. Em relação à turma do Curso de Licenciatura em Letras/Espanhol houve uma maior receptividade uma vez que é um Curso voltado para as Ciências Humanas. Ainda que percebamos o quanto uma disciplina por não fazer parte das especificidades do curso encontra resistência por parte dos estudantes, é importante mostrar aos mesmos sua relevância para sua formação e prática docente.

Por conta de todo aprendizado vivenciado durante a monitoria, pude constatar o que Pimenta (2000) defende sobre os saberes que configuram a docência, na qual destaca: (1) a experiência, como sendo um saber vivenciado durante a escolarização e saberes que produzem no seu cotidiano da atividade docente; (2) os pedagógicos, produzidos na ação, a partir do contato com os saberes sobre a educação e sobre a Pedagogia e (3) os saberes do conhecimento, isto é, ter a clareza da importância e do significado do conhecimento, do seu poder na vida das pessoas.

\section{Considerações}

Durante a realização da monitoria tive oportunidade de aprofundar nos saberes e conhecimentos relativos à disciplina Psicologia do Desenvolvimento, além de observar às atividades inerentes a prática docente de forma mais direta. Outro ponto que acrescentou nessa vivência foi poder perceber a didática empregada da professora, ao lidar com diferentes interesses e percepções dos estudantes de cada turma ao gerenciar a mesma disciplina. Isso nos reporta a Tardif (2007) quando afirma que os saberes docentes e a prática pedagógica são construídos a e reconstruídos pelo docente a partir do ensinar.

Dessa forma, a participação como monitora me fez entender, mais ainda, o quanto é relevante à disciplina Psicologia do desenvolvimento nos cursos de Licenciatura tanto ao que diz respeito suas contribuições na formação inicial do professor como também por propiciar um maior conhecimento sobre o comportamento humano.

\section{Referências}

BIAGgiO, A. M. B. Psicologia do Desenvolvimento. Petropólis-RJ: Vozes, 2008.

PIMENTA, S. G. (Org.). Saberes pedagógicos e atividade docente. São Paulo: Cortez, 2000.

TARDIF, M. Saberes docentes e Formação Profissional. Petropólis-RJ: Vozes, 2007. 